\title{
Analysing the Attitude of Social Media Users towards Ephemeral Marketing as a Digital Marketing Tool
}

\author{
Atharva Dange, Kavitha R Gowda, V R Srinidhi, D. Halaswamy
}

\begin{abstract}
In the twenty-first century, the rise of social media and social networking websites dramatically altered the communication environment. Web 2.0 social media is an effective tool for locating and targeting customers, engaging them with companies, and leaving a lasting impression on their minds. According to the findings, marketing and campaigning professionals have used Ephemeral content to build relationships with trendy communities, engage customers, increase sales, communicate offers and limited-time deals, and stay connected with a large audience by monetising "moment marketing" at times. Finally, this study reveals that users' goals increase gratification and improve engagement with ephemeral information on social media. It also suggests that the desire for closure can mitigate the impact of gratification on ephemeral content engagement. The Fear of Missing Out, as well as additional features such as an individual's interests and the immediacy of action taking in that precise time, are the most significant elements that keep the audience hooked on such Ephemeral Content. Ephemeral Content is on the rise, and it's a great way for companies to cash in on platform capabilities in a new and creative way.
\end{abstract}

Keywords: Digital Marketing, Social media Marketing, Ephemeral Marketing, Management

JEL Codes: M31, M37, M39

\section{Introduction}

People have used social media to interact with their social networks and exchange photographs and videos for years. Those days, however, are long gone, and social media has evolved into much more. It's evolved into a shopping site, a product discovery platform, and, most recently, a customer support channel. Many businesses have begun to see social media networks as platforms for providing customer care. This shift occurred gradually as businesses became aware that many customers attempted to contact them via social media. This may be due to a lack of response on other channels or simply because it was a more direct method of contacting the brands. Brands, of course, began reacting to such communications and guiding customers to the appropriate channels. Imagine multiplying the number of such encounters by a factor of ten in a few years. It's not simply a few instances where people ask questions or complain about brands on social media, and the brands respond. It has now established itself as a major enough customer care channel for brands to acknowledge it as such. It is also one of the most significant customer service channels, due to the severe consequences of poor customer service in front of other consumers. As a result, it's even more critical for brands to treat their customers well.

The ever-changing nature of social media results in a never-ending flood of buzzwords and trends. Ephemeral content is one of the newest buzzwords. Simply put, ephemeral material is any visual content - video or photo - that is only available for a limited time. The term literally means "temporary." The tendency in the digital era is for brands to use "storey" on social media platforms that expire after a set amount of time, usually 24 hours, for the purpose of advertising.

The word, popularised by Snapchat, has grown significant to some firms, while others have

\footnotetext{
Atharva Dange, e-mail: eatharva.dange@mba.christuniversity.in Kavitha R Gowda, e-mail: kavitha.rgowda@christuniversity.in V R Srinidhi, e-mail: srinidhi.vr@christuniversity.in D. Halaswamy, e mail: halaswamy.d@christuniversity.in

School of Business and Management, Christ Deemed-to-be University Bangalore, Karnataka India 
been sluggish or unwilling to adopt it. Snapchat's concept of sharing disappearing information has been adopted by major social media platforms such as Instagram, Facebook, and Whatsapp. Users can now share content that is only available for 24 hours via Stories and Live-stream. Various brands are employing it for a variety of goals, including but not limited to increasing sales, promoting limited-time specials, attracting crowds, and attracting the attention of their target audience.

\section{Literature Review:}

Snapchat interactions were seen as more pleasurable and connected with a higher happy mood than other communication platforms, according to Bayer, et al., (2016). Snapchat interactions were found to be associated with lower levels of social support than interactions on other platforms. The authors also claim that their qualitative data indicated Snapchat traits that may enhance pleasant affect (but not social support), such as sharing mundane events with close friends and a decrease in self-presentational concerns. Furthermore, when users were asked to compare Snapchat to face-to-face engagement, they said they paid more attention to Snapchat content than archived content, which could lead to bigger emotional rewards. Overall, the participants perceived Snapchat as a light-weight conduit for sharing unplanned experiences with friends, rather than a platform for sharing or viewing photographs. These findings add to our developing understanding of the influence of ephemeral social media on social bonds. The authors discovered that restricting the extent of social interaction can be useful in certain cases for specific types of user experiences. The experience sampling surveys revealed that Snapchat has more positive effects but less social support than other mediated channels, whereas interviews revealed how affordances, practises, and expectations - particularly around ephemerality - lead to people sharing small moments on Snapchat rather than big moments on Facebook. Taken together, the two studies help to define Snapchat's place in the social media ecosystem: a lightweight platform for sharing spontaneous experiences with friends.

Alhabash and Ma (2017) looked into the differences in intensity of use, daily time spent on the site, and motivations for using Facebook, Twitter, Instagram, and Snapchat among college students. The uses and gratifications (U\&G) technique was used to compare the four platforms. College students were asked to rank their use of Facebook, Twitter, Instagram, and Snapchat, as well as nine different reasons for doing so, in a cross-sectional poll. On a daily basis, participants spend the most time on Instagram, followed by Snapchat, Facebook, and Twitter. Snapchat and Instagram had the highest use intensity (nearly evenly), followed by Facebook and Twitter. Snapchat takes the lead in five of the nine reasons people use the app. The findings are discussed in relation to the U\&G strategy as well as the distinctions between various social media and social networking sites (SNSs). Because of the entertainment and user interface of ephemeral content and tales available on platforms, the author determined that Instagram, Snapchat, and Facebook are more popular than the other nine SNSs evaluated.

(Alexa K. Fox, Todd J. Bacile, Chinintorn Nakhata, Aleshia Weible. 2017) The research paper titled "Selfie-Marketing: Exploring Narcissism and Self-Concept in Visual UserGenerated Content on Social Media” examines selfie-marketing from a consumer behavior perspective. Creating and sharing selfies is gaining popularity among millennials. The authors seek to understand how this popularity relates to classic research on narcissism and selfconcept, and to determine the effectiveness of selfie-marketing in visual user-generated content. An examination of different visual content-sharing apps suggests that they should not be viewed as the same. Paper highlights the features of two of the most popular visual content- sharing platforms among millennials, Instagram and Snapchat to explain how millennials use different apps for self-presentation. Instagram and Snapchat both allow consumers to take and share selfies with ease, but they offer very different features, levels of privacy, and levels of permanency. The ephemerality of content matters. The findings suggest that narcissism positively relates to millennials' attitudes toward and intent to participate in selfie-marketing on visual content-sharing apps. Results also demonstrate that millennials seek to use selfies to present their self-concepts differently in various visual content-sharing. Environments. 
Anirban Ganguli, Shivane Mahajan, Shriyam Srivastava(2019) The researcher in the research paper titled "Attitude of Social Media Users towards Ephemeral Marketing” has laid emphasis on the attitude of social media users towards online ephemeral marketing. Author believes that Ephemeral marketing is one such concept being increasingly used by modern marketers in order to reach out to a larger target market and in order to increase the visibility of the products and services they offer. The study also aims to understand the level of awareness about ephemeral marketing amthe social media users. The findings of the study allow us to deduce whether this new trend in marketing, although being used widely amongst marketers, is at all a necessity currently, keeping in mind the proven success of other, already existing techniques (Ayedee \& Kumar, 2020; Kumar \& Aggarwal, 2018). The outcome examines whether the practice of this technique by the marketers has a positive or negative response from the consumers and also finds out if consumers pay attention to these trends. Findings shows that this form of ephemeral marketing has been further used not just on online platforms but also offline in the form of pop-up stores or temporary retail setups which exist for a very short period of time.

Chen \& Cheung (2019) investigated the power of ephemeral material by identifying its antecedents and implications in users' decision-making processes, and how it has been rapidly rising to become the latest social media buzzword. The users accepted ephemeral content for gratification based on factors including fear of missing out, trust, immediacy, and social pressure (Shaikh, Kumar, \& Syed, 2021; Kumar, Sowdamini, Manocha, \& Pujari, 2021). Users' gratification influenced their involvement with ephemeral information, and gratification moderated the links between motives and engagement. Most importantly, the desire for closure reduced the indirect effects of motives on engagement via gratification. The author suggested that the desire for closure can help to reduce the effect of gratification on ephemeral content engagement.

Flecha-Ortza, et al., (2019) examined how Millennials' self-expression on Snapchat influences the platform's use and user purchase motivations. This study employs partial least squares structural equation modelling to examine a set of hypotheses based on the uses and gratification (U\&G) hypothesis (PLS-SEM). The study was based on a sample of 454 millennial generation residents of Puerto Rico, show that dynamic factors play a significant role in Snapchat usage and reveal how gratification generated through Snapchat usage and interaction with product and service brand content influences purchase motivation. These findings support the U\&G theory by demonstrating how Snapchat's ephemeral content satisfies and influences Millennial expectations via an unconventional communicative technique that boosts product/service brand influence and relationships. Finally, this study demonstrates how selfexpression (i.e., dynamic factors) influences outcomes. Furthermore, the research demonstrates how Snapchat's communication paradigm increases the competitiveness among social networks to retain users. Finally, the researchers state that more research on the effects of marketing methods on Snapchat and their impact on Millennials is required.

Lucas Machado de Oliveira, Olga Goussevskaia, (2020) in the context of influencer marketing on Instagram, the study paper "Sponsored content and user engagement dynamics on Instagram" examines sponsored material and its impact on user engagement. The author gathered and described a huge number of Instagram profiles, and provided metrics to measure the impact of ad posting techniques on audience engagement over time. On a weekly basis, the author examines how the quantity of sponsored articles varies in relation to the amount of likes and comments. According to the authors, an increase in sponsored material might have a detrimental impact on audience engagement with an influencer's profile. However, research reveals that there are a number of strategies to offset this negative effect, including strategic use of hashtags and mentions, the textual content of a sponsored post, and seasonal information. According to the amount of their following, the author grouped the influencer profiles into three categories: novices, micro-influencers, and celebrities. When the amount of ad posts in a week is increased, celebrities are the ones that suffer the most. 


\section{Conceptual Framework}

Based on the research contribution, a model was developed to examine the role of certain factors which leads to the response towards the ephemeral content. The dependable and nondependable variables identified from the research are aligned as showcased below. The S-O-R (Stimulus Organism Response) model is a medium to understand the complexity of human behaviour. SOR Model in psychology suggests that feelings and behaviours are caused by the external environment and the ' $\mathrm{O}$ ' or the organism has an active and mediating function. In short, the stimulus organism response theory states that there's a stimulus that triggers a response based on the internal feelings or behaviour of an organism (person). This internal processing of the stimulus can be conscious or unconscious. It further triggers an emotion that leads to a response.

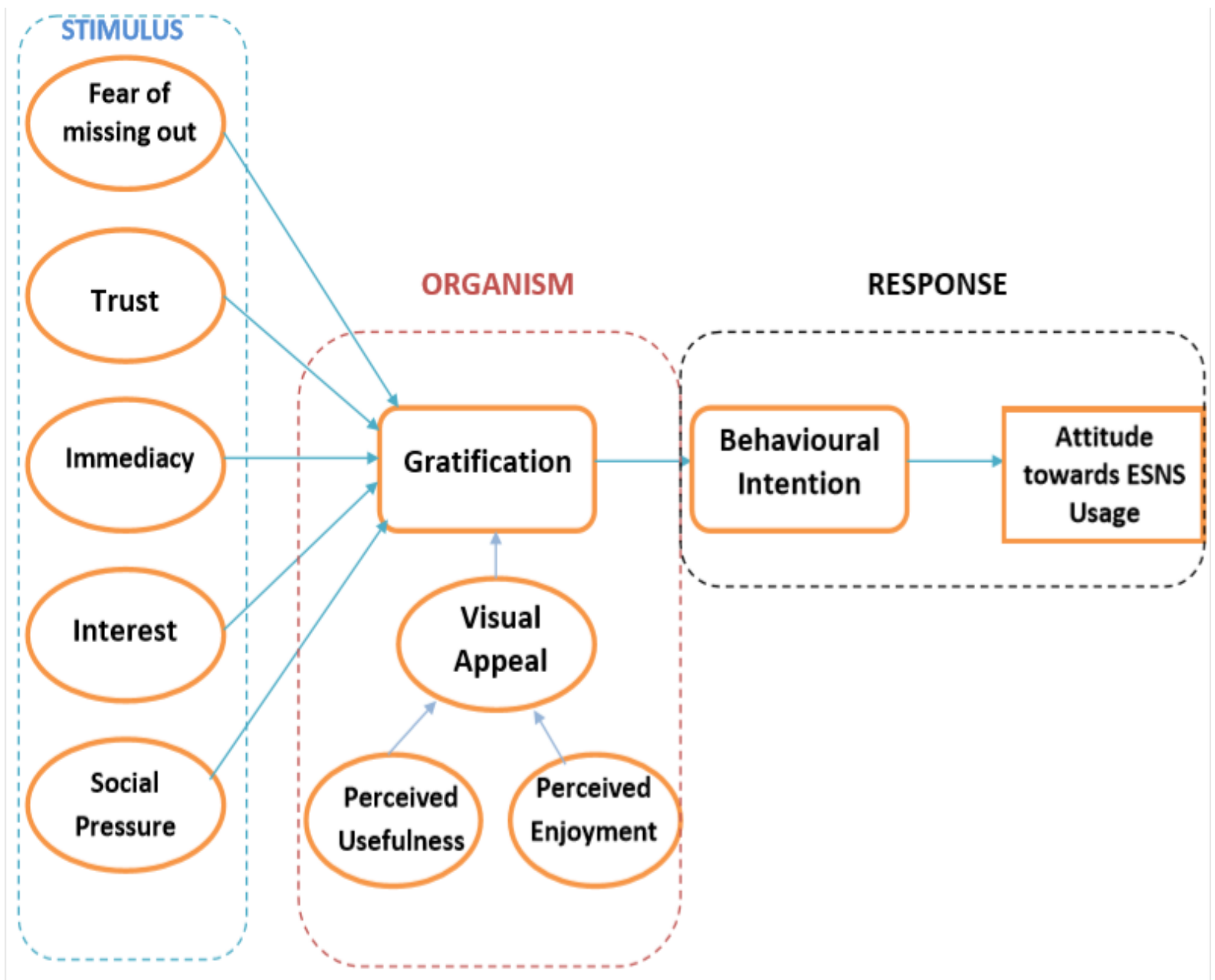

Fig. 1 Proposed SOR Model by Atharva Dange, Dr.Kavitha R Gowda, Dr V R SRINIDHI and Dr.Halaswamy D

\section{Purpose of the Study}

Our paper provides valuable information to marketers and businesses working on the online platforms to understand the behaviour of a customer towards social media and ephemeral content. As mentioned earlier, following Snapchat every other social media platform has introduced their own versions and ways of ephemeral content creation for users and the trend is growing. With the number of mobile users growing substantially over the past few years, use of social media platforms and eventually the usage of ephemeral content is becoming even more popular. 
Today, people's attention spans are short and the way they like to consume content has also changed. This is why content formats like Stories have become popular. They are short, engaging, and addictive in a way that people can spend hours scrolling through one Story after another.

This is evident by the substantial rise in Stories' daily active users, as shown below:

(Data Source: statista)

- Snapchat has 173 million daily active users

- Instagram Stories has 580 million

- Combined all platforms account for around 18 billion daily video-short stories views

- $53 \%$ of Snapchat users are under 34

- The spending power of Millennials is set to surpass $\$ 1$ trillion by 2021

- In 2020, over 3.6 billion people were using social media worldwide, a number projected to increase to almost 4.41 billion in 2025 .

Statistics prove that short-lived content keeps people hooked, which means an opportunity to deliver your brand message and delivering value for your customer. Plus, social media platforms are constantly investing in new and updated features to increase user engagement and keep people coming back for more. So, understanding and leveraging on this ephemeral content is very important as a marketer. This study talks about the customer perspective that whether the user is willing to accept these ways and platforms as a medium of advertising and their attitude towards it. All these questions will help marketer to decide the course of future of digital marketing in this way and will decide brands involvement on these platforms.

This study will help marketers to understand the acceptance of such short-lived content as well as will be useful for academician to understand Indian consumer's response to such evident changes in marketing pattern and their attitude towards it.

\section{Methods}

Use of social media is growing day by day and the purpose for which it can be and is used is changing enormously with the evolving nature of various social media platforms and the way users are exploiting the available features for the different purposes. This papers' focus is primarily on the ephemeral content and tries "To understand the usage of ephemeral content by brands on social media platforms as an advertising tool in Indian context and to analyse what demographic part of population entertains and accepts them."

The basic objectives of this study can be listed down as follows:

- To find out attitude of social media users towards ephemeral content

- To find out the factors leading to the usage of ephemerality on social media platforms.

- To find out effectiveness of ephemeral content usage as an advertising tool for brands

- To understand the demographics of netizens who actively uses the social media platforms and accepts usage of ephemerality for advertising

- To find out the brands currently using ephemeral contents for advertising (in Indian context).

The research methodology applied in this study adopted an innovative way to explore and capture prospective consumer attitudes towards ephemeral content as an advertisement tool of brands and to understand which kind of users accepts these brands and also to check which brands are putting efforts in using ephemerality as a tool to connect with audience. Research design is divided in 3 parts as follows: 
Stage I: This involved data collection from various sources such as articles, journals, blogs, research papers, government publications, and company literature and industry findings. This provided assist in understanding ephemerality, ephemeral content, its usage and ways of using them in practice and the concepts behind it.

Stage II: At this stage, primary research is conducted. The target population of the study is young consumers who are currently active users of social media platforms like Instagram, Facebook and Twitter but take into consideration the opinion of all age groups. Primary data has been collected by a well-designed questionnaire online through google forms which was distributed among 377 individuals of all classes consisting of questions related to variables of our research model and other questions based on demographic distributions. Close ended questions were asked to the respondents measured five-point Likert scale (5 strongly agree to 1 strongly disagree). Convenient sampling technique is adapted along with pilot testing to remove any pre requisite errors in the data.

Stage III: Studying brands using ephemeral contents on these social media platforms as a tool for advertising and connecting with the netizens. In-depth study and analysis of these brands is done. Also, various social media pages on instagram such as Mad over Marketing, TDM, Marketing Fundas, Marketing Minds etc. were observed to increase the reachability towards various brands using these tools for advertising. Current practices and trends and recent content created by brands and shared by net users and target population were studied and focused on.

\section{Data analysis tools}

After the collection of the responses, data was further analysed by applying different statistical tools. Firstly, reliability analysis was used in order to generate Cronbach's Alpha value and frequency analysis was used in order to mean. This was done by using the option of Descriptive Analysis in IBM SPSS STATISTICS 25.0. After these analysis, Kaiser-Meyer-Olkin (KMO) and Bartlett's test has been run. Hypotheses testing using Regression is performed. Regression is performed to predict the value of a dependent variable based on the value of an independent variable.

\section{Data analysis \& interpretation}

Data analysis is divided in two parts. The first one document the test conducted using SPSS IBM tool and the second offers an analysis under the netnography study i.e., observing the Social Media Platforms and pages of brands to evaluate and achieve the mentioned objective of the paper.

\section{Part-I}

\section{Demographic profile}

The Tables below represent the demographic profile of the 377 respondents whose opinions were collected via the primary data collection technique through questionnaire.

\section{Frequency Distribution of Demographic profile:}

Table 1 Age

\begin{tabular}{|r|l|r|r|r|r|}
\hline \multicolumn{2}{|c|}{ Age } \\
\hline \multirow{5}{*}{ Valid } & Frequency & Percent & Valid Percent & $\begin{array}{c}\text { Cumulative } \\
\text { Percent }\end{array}$ \\
\cline { 2 - 6 } & $15-20$ & 46 & 12.2 & 12.2 & 12.2 \\
\cline { 2 - 6 } & $21-26$ & 237 & 62.9 & 62.9 & 75.1 \\
\cline { 2 - 6 } & $27-32$ & 58 & 15.4 & 15.4 & 90.5 \\
\cline { 2 - 7 } & 39 and above & 36 & 9.5 & 9.5 & 100.0 \\
\cline { 2 - 7 } & Total & 377 & 100.0 & 100.0 & \\
\hline
\end{tabular}


Table 2 Gender

\begin{tabular}{|r|l|r|r|r|r|}
\hline \multicolumn{2}{|c|}{} & Frequency & Percent & Valid Percent & \multicolumn{1}{c|}{$\begin{array}{c}\text { Cumulative } \\
\text { Percent }\end{array}$} \\
\hline \multirow{3}{*}{ Valid } & Female & 139 & 36.9 & 36.9 & 36.9 \\
\cline { 2 - 6 } & Male & 238 & 63.1 & 63.1 & 100.0 \\
\cline { 2 - 6 } & Total & 377 & 100.0 & 100.0 & \\
\hline
\end{tabular}

Table 3 Education Level

\begin{tabular}{|l|l|r|r|r|r|}
\hline \multicolumn{2}{|c|}{ Education Level } \\
\hline & $\begin{array}{c}\text { Frequenc } \\
\text { y }\end{array}$ & Percent & \multicolumn{1}{|c|}{$\begin{array}{c}\text { Valid } \\
\text { Percent }\end{array}$} & $\begin{array}{c}\text { Cumulative } \\
\text { Percent }\end{array}$ \\
\hline \multirow{4}{*}{$\begin{array}{l}\text { Vali } \\
\text { d }\end{array}$} & Bachelor's Degree & 106 & 28.1 & 28.1 & 28.1 \\
\cline { 2 - 6 } & Master's Degree & 259 & 68.7 & 68.7 & 96.8 \\
\cline { 2 - 6 } & Ph.D. & 12 & 3.2 & 3.2 & 100.0 \\
\cline { 2 - 6 } & Total & 377 & 100.0 & 100.0 & \\
\hline
\end{tabular}

Table 4 Occupation

\begin{tabular}{|c|c|c|c|c|c|}
\hline \multicolumn{6}{|c|}{ Occupation } \\
\hline & & $\begin{array}{c}\text { Frequenc } \\
\mathbf{y}\end{array}$ & Percent & $\begin{array}{c}\text { Valid } \\
\text { Percent }\end{array}$ & $\begin{array}{c}\text { Cumulative } \\
\text { Percent }\end{array}$ \\
\hline \multirow{5}{*}{$\begin{array}{l}\text { Vali } \\
\text { d }\end{array}$} & Student & 259 & 68.7 & 68.7 & 68.7 \\
\hline & Unemployed & 12 & 3.2 & 3.2 & 71.9 \\
\hline & $\begin{array}{l}\text { Working } \\
\text { Professional }\end{array}$ & 94 & 24.9 & 24.9 & 96.8 \\
\hline & Retired & 12 & 3.2 & 3.2 & 100.0 \\
\hline & Total & 377 & 100.0 & 100.0 & \\
\hline
\end{tabular}

Table 5 Family Income

\begin{tabular}{|c|c|c|c|c|c|}
\hline \multicolumn{6}{|c|}{ Family Income } \\
\hline & & $\begin{array}{c}\text { Frequenc } \\
y\end{array}$ & Percent & $\begin{array}{c}\text { Valid } \\
\text { Percent }\end{array}$ & $\begin{array}{c}\text { Cumulative } \\
\text { Percent }\end{array}$ \\
\hline \multirow{5}{*}{$\begin{array}{l}\text { Vali } \\
\text { d }\end{array}$} & 3-7 Lakh & 60 & 15.9 & 15.9 & 15.9 \\
\hline & 8-12 Lakh & 202 & 53.6 & 53.6 & 69.5 \\
\hline & 13-17 Lakh & 92 & 24.4 & 24.4 & 93.9 \\
\hline & $\begin{array}{l}18 \text { Lakh and } \\
\text { above }\end{array}$ & 23 & 6.1 & 6.1 & 100.0 \\
\hline & Total & 377 & 100.0 & 100.0 & \\
\hline
\end{tabular}


- From the above attached tables of Demographic profile of the 377 respondents, it is observed that the Male respondents are more in number dominating with $\mathbf{6 3 . 1 \%}$ while responses comprised of $\mathbf{3 6 . 9 \%}$ female individuals.

- Majority of the respondents of the age bracket $21-26$ which is $62.9 \%$ \& the minority of the respondents are from the age bracket of 39 and above which is $\mathbf{9 . 5 \%}$ only.

- Maximum responses were received by Post Graduates which were $\mathbf{6 8 . 7 \%}$ of the total whereas only $\mathbf{3 . 2 \%}$ of the total responses were received by PhD's.

- $\mathbf{6 8 . 7 \%}$ of the survey was answered by students, followed by $\mathbf{2 4 . 9 \%}$ by Working Professionals whereas Unemployed and Retired respondents were $\mathbf{6 . 4 \%}$ of the total.

- With 53.6\%, majority of the respondents were comprised of income bracket of 8-12 Lakh per annum.

\section{Reliability analysis}

After studying the profile of the respondents, the data is used for further analysis. Exploratory factor analysis was performed by using SPSS. Table represents the result of Reliability test done on the collected data and the value of the Cronbach's alpha. According to (Cavana, 2001) reliability tests help in knowing the consistency and stability of the instruments used in the survey. Cronbach alpha is a well-known approach to test the reliability of the data. The value of the Cronbach alpha with a range greater than 0.70 is considered acceptable and good. The value of the Cronbach's alpha represents the internal consistency of the items (Arif et al, 2016). From the table, we can see that the Cronbach's Alpha obtained is 0.885 which is greater than 0.6. This shows the data collected for the research is reliable and further research can be done using the data.

Table 6 Reliability Analysis

\begin{tabular}{|r|rr|}
\hline \multicolumn{2}{|l|}{ Reliability Statistics } \\
\hline Cronbach's Alpha & No. of Items \\
\hline .885 & & 18 \\
\hline
\end{tabular}

Sampling adequacy test (KMO and Bartlett's test)

Kaiser-Meyer-Olkin (KMO) Test is a measure of how suited the data is for factor analysis. The test measures sampling adequacy for each variable in the model and for the complete model. Table shows two measurements showing the adequacy of the data for structure detection. The Kaiser-Meyer-Olkin Measure of Sampling Adequacy is a statistic that indicates the proportion of variance in the variables that may be caused by the underlying factors. High values (close to 1.0) generally indicate that a factor analysis may be useful for your data. If the value is less than 0.50 , the results of the analysis of the factor may not be very useful and remedial action needs to be taken. The table shows the value obtained for KMO and Bartlett's Test is 0.816 which is more than 0.50 . This infers that the data collected is adequate for the structure detection and for further analysis.t

Table 7 Sample Adequacy Test output

\begin{tabular}{|l|l|r|}
\hline \multicolumn{3}{|c|}{ KMO and Bartlett's Test } \\
\hline Kaiser-Meyer-Olkin Measure of Sampling Adequacy. & $\mathbf{. 8 1 6}$ \\
\hline \multirow{3}{*}{ Bartlett's Test of Sphericity } & Approx. Chi-Square & 5893.167 \\
\cline { 2 - 3 } & df & 153 \\
\hline
\end{tabular}


Sig.

\section{One-Way ANOVA TEST}

One-Way ANOVA ("analysis of variance") compares the means of two or more independent groups in order to determine whether there is statistical evidence that the associated population means are significantly different. The One-Way ANOVA is commonly used to test the following:

- Statistical differences among the means of two or more groups

- Statistical differences among the means of two or more interventions

- Statistical differences among the means of two or more change scores

Table 8 ANOVA Output (Influence of Age over attitude towards usage of ESNS)

\begin{tabular}{|c|c|c|c|c|c|c|}
\hline \multicolumn{7}{|c|}{ ANOVA } \\
\hline & & $\begin{array}{l}\text { Sum of } \\
\text { Squares }\end{array}$ & $\mathrm{df}$ & Mean Square & $\mathrm{F}$ & Sig. \\
\hline \multirow{3}{*}{$\begin{array}{l}\text { KnowledgeAV } \\
\text { G }\end{array}$} & Between Groups & 17.708 & 3 & 5.903 & 19.518 & .000 \\
\hline & Within Groups & 112.803 & 373 & .302 & & \\
\hline & Total & 130.511 & 376 & & & \\
\hline \multirow{3}{*}{ TrustAVG } & Between Groups & 19.115 & 3 & 6.372 & 31.867 & .000 \\
\hline & Within Groups & 74.578 & 373 & .200 & & \\
\hline & Total & 93.692 & 376 & & & \\
\hline \multirow{3}{*}{ VappealAVG } & Between Groups & 19.101 & 3 & 6.367 & 30.249 & .000 \\
\hline & Within Groups & 78.511 & 373 & .210 & & \\
\hline & Total & 97.611 & 376 & & & \\
\hline \multirow{3}{*}{ FomoAVG } & Between Groups & 21.978 & 3 & 7.326 & 21.780 & .000 \\
\hline & Within Groups & 125.465 & 373 & .336 & & \\
\hline & Total & 147.443 & 376 & & & \\
\hline \multirow{3}{*}{$\begin{array}{l}\text { SopressureAV } \\
\text { G }\end{array}$} & Between Groups & 10.202 & 3 & 3.401 & 5.098 & .002 \\
\hline & Within Groups & 248.832 & 373 & .667 & & \\
\hline & Total & 259.034 & 376 & & & \\
\hline \multirow{3}{*}{$\begin{array}{l}\text { IntentionAttiA } \\
\text { VG }\end{array}$} & Between Groups & 15.882 & 3 & 5.294 & 25.551 & .000 \\
\hline & Within Groups & 77.282 & 373 & .207 & & \\
\hline & Total & 93.164 & 376 & & & \\
\hline
\end{tabular}

Table 9 Descriptives

\begin{tabular}{|c|c|c|c|c|c|c|c|c|c|}
\hline \multicolumn{10}{|c|}{ Descriptives } \\
\hline & & \multirow[t]{2}{*}{$\mathrm{N}$} & \multirow[t]{2}{*}{$\begin{array}{c}\text { Mea } \\
\mathrm{n}\end{array}$} & \multirow{2}{*}{$\begin{array}{l}\text { Std. } \\
\text { Deviati } \\
\text { on }\end{array}$} & \multirow[t]{2}{*}{$\begin{array}{l}\text { Std. } \\
\text { Error }\end{array}$} & \multicolumn{2}{|c|}{$\begin{array}{l}\text { 95\% Confidence } \\
\text { Interval for Mean }\end{array}$} & \multirow[t]{2}{*}{$\begin{array}{l}\text { Mini } \\
\text { mum }\end{array}$} & \multirow[t]{2}{*}{$\begin{array}{l}\text { Maxi } \\
\text { mum }\end{array}$} \\
\hline & & & & & & $\begin{array}{l}\text { Lower } \\
\text { Bound }\end{array}$ & $\begin{array}{l}\text { Upper } \\
\text { Bound }\end{array}$ & & \\
\hline \multirow{2}{*}{$\begin{array}{l}\text { KnowledgeAV } \\
\text { G }\end{array}$} & $15-20$ & 46 & $\begin{array}{r}4.88 \\
04\end{array}$ & .21563 & $\begin{array}{r}.031 \\
79\end{array}$ & 4.8164 & 4.9445 & 4.50 & 5.00 \\
\hline & $21-26$ & 237 & $\begin{array}{r}4.49 \\
37\end{array}$ & .65497 & $\begin{array}{r}.042 \\
54\end{array}$ & 4.4099 & 4.5775 & 2.50 & 5.00 \\
\hline
\end{tabular}




\begin{tabular}{|c|c|c|c|c|c|c|c|c|c|}
\hline & $27-32$ & 58 & $\begin{array}{r}4.69 \\
83\end{array}$ & .40760 & $\begin{array}{r}.053 \\
52\end{array}$ & 4.5911 & 4.8054 & 4.00 & 5.00 \\
\hline & $\begin{array}{l}39 \text { and } \\
\text { above }\end{array}$ & 36 & $\begin{array}{r}4.00 \\
00\end{array}$ & .00000 & $\begin{array}{r}.000 \\
00\end{array}$ & 4.0000 & 4.0000 & 4.00 & 4.00 \\
\hline & Total & 377 & $\begin{array}{r}4.52 \\
52\end{array}$ & .58915 & $\begin{array}{r}.030 \\
34\end{array}$ & 4.4655 & 4.5849 & 2.50 & 5.00 \\
\hline \multirow{5}{*}{ TrustAVG } & $15-20$ & 46 & $\begin{array}{r}4.36 \\
96\end{array}$ & .41412 & $\begin{array}{r}.061 \\
06\end{array}$ & 4.2466 & 4.4925 & 4.00 & 5.00 \\
\hline & $21-26$ & 237 & $\begin{array}{r}4.44 \\
30 \\
\end{array}$ & .52271 & $\begin{array}{r}.033 \\
95 \\
\end{array}$ & 4.3761 & 4.5099 & 3.50 & 5.00 \\
\hline & $27-32$ & 58 & $\begin{array}{r}4.89 \\
66\end{array}$ & .20431 & $\begin{array}{r}.026 \\
83\end{array}$ & 4.8428 & 4.9503 & 4.50 & 5.00 \\
\hline & $\begin{array}{l}39 \text { and } \\
\text { above }\end{array}$ & 36 & $\begin{array}{r}4.00 \\
00 \\
\end{array}$ & .00000 & $\begin{array}{r}.000 \\
00 \\
\end{array}$ & 4.0000 & 4.0000 & 4.00 & 4.00 \\
\hline & Total & 377 & $\begin{array}{r}4.46 \\
15\end{array}$ & .49918 & $\begin{array}{r}.025 \\
71 \\
\end{array}$ & 4.4110 & 4.5121 & 3.50 & 5.00 \\
\hline \multirow{5}{*}{ VappealAVG } & $15-20$ & 46 & $\begin{array}{r}4.86 \\
96\end{array}$ & .22198 & $\begin{array}{r}.032 \\
73\end{array}$ & 4.8036 & 4.9355 & 4.50 & 5.00 \\
\hline & $21-26$ & 237 & $\begin{array}{r}4.47 \\
05\end{array}$ & .56107 & $\begin{array}{r}.036 \\
45\end{array}$ & 4.3987 & 4.5423 & 3.50 & 5.00 \\
\hline & $27-32$ & 58 & $\begin{array}{r}5.00 \\
00 \\
\end{array}$ & .00000 & $\begin{array}{r}.000 \\
00 \\
\end{array}$ & 5.0000 & 5.0000 & 5.00 & 5.00 \\
\hline & $\begin{array}{l}39 \text { and } \\
\text { above }\end{array}$ & 36 & $\begin{array}{r}4.33 \\
33 \\
\end{array}$ & .23905 & $\begin{array}{r}.039 \\
84 \\
\end{array}$ & 4.2525 & 4.4142 & 4.00 & 4.50 \\
\hline & Total & 377 & $\begin{array}{r}4.58 \\
75 \\
\end{array}$ & .50951 & $\begin{array}{r}.026 \\
24\end{array}$ & 4.5359 & 4.6391 & 3.50 & 5.00 \\
\hline \multirow{5}{*}{ FomoAVG } & $15-20$ & 46 & $\begin{array}{r}4.54 \\
78 \\
\end{array}$ & .36862 & $\begin{array}{r}.054 \\
35 \\
\end{array}$ & 4.4384 & 4.6573 & 4.00 & 5.00 \\
\hline & $21-26$ & 237 & $\begin{array}{r}4.17 \\
05\end{array}$ & .69889 & $\begin{array}{r}.045 \\
40\end{array}$ & 4.0810 & 4.2599 & 2.60 & 5.00 \\
\hline & $27-32$ & 58 & $\begin{array}{r}4.59 \\
31 \\
\end{array}$ & .25674 & $\begin{array}{r}.033 \\
71 \\
\end{array}$ & 4.5256 & 4.6606 & 4.20 & 4.80 \\
\hline & $\begin{array}{l}39 \text { and } \\
\text { above }\end{array}$ & 36 & $\begin{array}{r}3.73 \\
33 \\
\end{array}$ & .09562 & $\begin{array}{r}.015 \\
94 \\
\end{array}$ & 3.7010 & 3.7657 & 3.60 & 3.80 \\
\hline & Total & 377 & $\begin{array}{r}4.23 \\
98 \\
\end{array}$ & .62621 & $\begin{array}{r}.032 \\
25 \\
\end{array}$ & 4.1764 & 4.3032 & 2.60 & 5.00 \\
\hline \multirow{5}{*}{ SopressureAVG } & $15-20$ & 46 & $\begin{array}{r}3.36 \\
96\end{array}$ & .56209 & $\begin{array}{r}.082 \\
88\end{array}$ & 3.2026 & 3.5365 & 2.50 & 4.00 \\
\hline & $21-26$ & 237 & $\begin{array}{r}3.81 \\
65 \\
\end{array}$ & .94053 & $\begin{array}{r}.061 \\
09 \\
\end{array}$ & 3.6961 & 3.9368 & 1.50 & 5.00 \\
\hline & $27-32$ & 58 & $\begin{array}{r}3.68 \\
10 \\
\end{array}$ & .67342 & $\begin{array}{r}.088 \\
42 \\
\end{array}$ & 3.5040 & 3.8581 & 3.00 & 5.00 \\
\hline & $\begin{array}{l}39 \text { and } \\
\text { above }\end{array}$ & 36 & $\begin{array}{r}4.00 \\
00 \\
\end{array}$ & .00000 & $\begin{array}{r}.000 \\
00 \\
\end{array}$ & 4.0000 & 4.0000 & 4.00 & 4.00 \\
\hline & Total & 377 & $\begin{array}{r}3.75 \\
86 \\
\end{array}$ & .83001 & $\begin{array}{r}.042 \\
75 \\
\end{array}$ & 3.6746 & 3.8427 & 1.50 & 5.00 \\
\hline \multirow{4}{*}{$\begin{array}{l}\text { IntentionAttiA } \\
\text { VG }\end{array}$} & $15-20$ & 46 & $\begin{array}{r}4.74 \\
35 \\
\end{array}$ & .22176 & $\begin{array}{r}.032 \\
70 \\
\end{array}$ & 4.6776 & 4.8093 & 4.40 & 5.00 \\
\hline & $21-26$ & 237 & $\begin{array}{r}4.38 \\
48 \\
\end{array}$ & .55550 & $\begin{array}{r}.036 \\
08 \\
\end{array}$ & 4.3137 & 4.4559 & 3.20 & 5.00 \\
\hline & $27-32$ & 58 & $\begin{array}{r}4.84 \\
48\end{array}$ & .15006 & $\begin{array}{r}.019 \\
70\end{array}$ & 4.8054 & 4.8843 & 4.60 & 5.00 \\
\hline & $\begin{array}{l}39 \text { and } \\
\text { above }\end{array}$ & 36 & $\begin{array}{r}4.20 \\
00\end{array}$ & 16562 & $\begin{array}{r}.027 \\
60\end{array}$ & 4.1440 & 4.2560 & 4.00 & 4.40 \\
\hline
\end{tabular}




\begin{tabular}{|l|l|r|r|r|r|r|r|r|r|}
\hline & Total & 377 & 4.48 & .49777 & .025 & 4.4313 & 4.5321 & 3.20 & 5.00 \\
\hline
\end{tabular}

H1a: There is an influence of age on the consumer's usage attitude behaviour towards Ephemeral Social Networking Sites (ESNS).

H1b: There is no influence of age on the consumer's usage attitude behaviour towards Ephemeral Social Networking Sites (ESNS).

One-way Anova is used to determine whether there are any significant differences between the ordinal variables and other dependent and independent variable.

In the above study it is seen that if there is any significant effect of age on the various variables identified as the factors influencing the memes sharing behaviour. It was studied from the table that, none of the means of the age see a difference of more than 0.1 as all the significance value is $>0.05$. Thus, it is concluded from here that there is no influence of age in any of the variables. Therefore, we accept H0 i.e., H1b.

\section{Regression analysis (Influence of Independent variables on Dependent Variables)}

Regression analysis is a statistical tool used to measure the relationship between a dependent variable and an independent variable. It allows you to examine the relationship between two or more variables of interest. While there are many types of regression analysis, at their core they all examine the influence of one or more independent variables on a dependent variable.

The hypotheses formulated between relationship commitment and its corresponding antecedents are as follows:

\section{Fear of Missing Out}

H2a: There is no significant relation between FOMO and the Intention and Attitude towards ESNS usage.

H2b: There is significant relation between FOMO and the Intention and Attitude towards ESNS usage.

\section{Trust}

H3a: There is no significant relation between Trust and the Intention and Attitude towards ESNS usage.

H3b: There is significant relation between Trust and the Intention and Attitude towards ESNS usage.

\section{Immediacy}

H4a: There is no significant relation between Immediacy and the Intention and Attitude towards ESNS usage.

H4b: There is significant relation between Immediacy and the Intention and Attitude towards ESNS usage.

\section{Interests}

H5a: There is no significant relation between Interests and the Intention and Attitude towards ESNS usage.

H5b: There is significant relation between Interests and the Intention and Attitude towards ESNS usage.

\section{Social Pressure}


H6a: There is no significant relation between Social Pressure and the Intention and Attitude towards ESNS usage.

H6b: There is significant relation between Social Pressure and the Intention and Attitude towards ESNS usage.

\section{Visual Appeal}

H7a: There is no significant relation between Immediacy and the Intention and Attitude towards ESNS usage.

H7b: There is significant relation between Immediacy and the Intention and Attitude towards ESNS usage.

The first table of interest is the Model Summary table, as shown below:

Table 10 Model Summary

\begin{tabular}{|l|r|r|r|r|}
\hline \multicolumn{5}{|c|}{ Model Summary } \\
\hline Model & $\mathrm{R}$ & R Square & Adjusted R Square & $\begin{array}{c}\text { Std. Error of the } \\
\text { Estimate }\end{array}$ \\
\hline 1 & $.793^{\mathrm{a}}$ & .728 & .713 & .30550 \\
\hline
\end{tabular}

a. Predictors: (Constant), sopressureAVG, knowledgeAVG, vappealAVG, fomoAVG, trustAVG

This table provides the $\mathrm{R}$ and $\mathrm{R} 2$ values. The $\mathrm{R}$ value represents the simple correlation and is 0.793 (the "R" Column), which indicates a high degree of correlation. The R2 value (the "R Square" column) indicates how much of the total variation in the dependent variable can be explained by the independent variable. In this case, $72.8 \%$ can be explained, which is very large.

The next table is the ANOVA table, which reports how well the regression equation fits the data (i.e., predicts the dependent variable) and is shown below:

Table 11 Anova Output (Regression)

\begin{tabular}{|c|c|c|c|c|c|c|}
\hline \multicolumn{7}{|c|}{ ANOVA $^{a}$} \\
\hline \multicolumn{2}{|c|}{ Model } & Sum of & df & Mean Square & $\mathrm{F}$ & Sig. \\
\hline \multirow{3}{*}{1} & Regression & 58.539 & 5 & 11.708 & 125.446 & $.000^{\mathrm{b}}$ \\
\hline & Residual & 34.625 & 371 & .093 & & \\
\hline & Total & 93.164 & 376 & & & \\
\hline \multicolumn{7}{|c|}{ a. Dependent Variable: IntentionAttiAVG } \\
\hline \multicolumn{7}{|c|}{ b. Predictors: (Constant), sopressureAVG, knowledgeAVG, vappealAVG, fomoAVG, trustAVG } \\
\hline
\end{tabular}

This table indicates that the regression model predicts the dependent variable significantly well as it is visible by looking at the "Regression" row and go to the "Sig." column. This indicates the statistical significance of the regression model that was run. Here, $p<0.0005$, which is less than 0.05 , and indicates that, overall, the regression model statistically significantly predicts the outcome variable (i.e., it is a good fit for the data). 
Table 12 Coeffients (Regression) (influence of knowledge, trust, FOMO, visual appeal and social pressure on Intention Attitude)

\begin{tabular}{|c|c|c|c|c|c|c|}
\hline \multicolumn{7}{|c|}{ Coefficients $^{\mathbf{a}}$} \\
\hline \multirow{2}{*}{\multicolumn{2}{|c|}{ Model }} & \multicolumn{2}{|c|}{$\begin{array}{l}\text { Unstandardized } \\
\text { Coefficients }\end{array}$} & \multirow{2}{*}{$\begin{array}{c}\begin{array}{c}\text { Standardized } \\
\text { Coefficients }\end{array} \\
\text { Beta }\end{array}$} & \multirow[t]{2}{*}{$\mathrm{t}$} & \multirow[t]{2}{*}{ Sig. } \\
\hline & & B & Std. Error & & & \\
\hline \multirow{6}{*}{1} & (Constant) & .455 & .174 & & 2.608 & .009 \\
\hline & $\begin{array}{l}\text { knowledgeAV } \\
\text { G }\end{array}$ & .120 & .035 & .142 & 3.455 & .001 \\
\hline & trustAVG & .208 & .052 & .208 & 4.000 & .000 \\
\hline & vappealAVG & .532 & .039 & .544 & 13.611 & .000 \\
\hline & fomoAVG & .044 & .038 & .055 & 1.137 & .000 \\
\hline & $\begin{array}{l}\text { sopressureAV } \\
\text { G }\end{array}$ & -.019 & .022 & -.031 & -.855 & .393 \\
\hline
\end{tabular}

The Coefficients table provides us with the necessary information to predict Dependent variable from Independent, as well as determine whether independent variable contributes statistically significantly to the model (by looking at the "Sig." column).

From the above tables, it can be analysed that:

H1 (0.000), H2 (0.001), H3 (0.000), H4 (0.000), H5 (0.000), H6 (0.000), have significant value less than 0.05; therefore, we reject the null hypothesis whereas $\mathrm{H} 7$ (0.393) has value more than 0.05; therefore, we accept the null hypothesis and reject the alternative hypothesis in this case.

Consequently, the following findings are implied about these hypotheses:

- In the case of H1 there is a significant relationship between age on the consumer's usage attitude behaviour towards Ephemeral Social Networking Sites (ESNS). So, we REJECT H0 i.e., H1a.

- In the case of H2, there is a significant relationship between FOMO and the Intention and Attitude towards ESNS usage. So, we REJECT H0 i.e., H2a.

- In the case of H3, there is a significant relationship between Trust and the Intention and Attitude towards ESNS usage. So, we REJECT H0 i.e., H3a.

- In case of H4 there is a significant relationship between Immediacy and the Intention and Attitude towards ESNS usage. So, we REJECT H0 i.e., H4a.

- In case of H5 there is a significant relationship between Interests and the Intention and Attitude towards ESNS usage. So, we REJECT H0 i.e., H5a.

- In case of $\mathrm{H6}$ there is a significant relationship between Visual Appeal and the Intention and Attitude towards ESNS usage. So, we REJECT H0 i.e., H6a.

- In case of H7 there is no significant relationship between Social Pressure and the Intention and Attitude towards ESNS usage. So, we REJECT H1 i.e., H7b and ACCEPT H0 i.e., H7a. 
Furthermore, we can use the values in the "B" column under the "Unstandardized Coefficients" column, as shown below to present the regression equation as:

\section{IntentionAttiAVG $=0.120 *$ knowledgeAVG + .208*trustAVG + .532*vappealAVG + $.044 *$ fomoAVG + (-.019) + .455}

\section{PART II}

\section{Netnography Study}

The various features like Ephemerality over the Social Media Platforms keeps on evolving and creatively bringing the new forms and hence these platforms are essentially viewed as 'slice of life' or humorous content pieces that are able to connect to a larger population who uses them. They derive their existence from anything that has captured the interest of the larger population. They could become an important way of what is called 'real time' or 'moment marketing' on social media by creatively using the available features to the fullest.

As mentioned earlier, the Ephemeral format came into existence with Snapchat and later on followed by various Social Media Platforms and its popularity has grown to such an extent that even Message exchange platforms like Whatsapp and Professional platforms like LinkedIn also have joined the race by putting these features for their customer base.

Although the Stories format is not that of a relatively new feature, 900 million people use them every day, with more than one-third of the most viewed stories being posted by businesses followed by the stories of influencers. 2/3rd of Instagram business users have posted stories, and according to TechCrunch, two in five of those posts receives a direct message from users which is a great number as compared to the cost associated with the content creation on these platform and is far efficient than the traditional method of acquiring the new customers or getting interest generated among the existing customers.

To understand the themes behind these popular Ephemeral contents created by the brands on these ESNS platform, and to observe which Brands are active on these platforms and use the features for advertising purposes, various online communities and groups were joined on different platforms like Instagram, Sapchat, and Facebook to get a 360-degree view of the variety of content circulated on these popular social media platforms. Also, official pages and handles of various brands were followed and observed along with various pages like Mad over Marketing, TDM, Marketing Fundas, etc. so that even if the Stories/Content on official brand handles and pages vanishes after 24 hours and is missed still it can be seen on these Marketing pages covering such interesting efforts by the brands. These two social media sites (Instagram and Facebook) were focused primarily because of the huge demand and usage by the respondents as obtained from primary study.

As a marketing strategy, Ephemeral Content is a temporary content that takes advantage of the fear of missing out (FOMO) and is designed to elicit an immediate response from the users. As seen and observed, Brands uses the Ephemeral content on Social Media Networks for different purposes which can be explained as follows:

- Get Immediate Response: Perhaps the most obvious goal is to elicit an immediate response from the user or viewer. The immediate goal may be for the user to make a quick purchasing decision or quick signup. For this purpose, various features of ESNS are used like Links are put-up to click on or "Swipe-up" features are put in order to get the customers to the right website directly. This way, customers' convenience is also taken care of. Brands are also observed giving away information along with these ads like No minimum Order Value or Coupon Codes for limited time offers.

- Increase User Engagement: Ephemeral content not only allows for the business to impress its product or service upon the user but also allows the user to engage in the brand on a more personal level. Stories are basically involved with increasing the interaction with the brands, put in efforts to be part of it and stay with trends. Whether it's the ability to edit and 
manipulate images, or an invitation to create a brand-related image or story, ephemeral marketing strategies invite the user to act on a brand's behalf.

- Endorsements by social media users: brands showcase their limited time deals by putting it across, the ESNS platforms via the handles of Influencers and Social Media Stars. These influencers are the individuals who endorses these brands in different way, like by showcasing the product usage or highlighting its benefits like Celebrities endorsing the Skin-care products of particular brand as their day care routine or by using the product themselves like wearing the apparels and advertising the limited time deals. Attached below is the example of social media influencer putting across a short time story for a brand Mochi Shoes and advertising the limited time $50 \%$ off deal.

- Informing the customers: Brands also uses the ephemeral contents to inform the customers about the new product launched or opening of a new store (Starbucks) along with limited time deals, upcoming/ongoing sales, special offers and discounts.

\section{Results}

As seen from the analysis conducted, firstly, this research addresses users' motivations for selecting and using social media platforms in the context of ephemeral content. The findings identify critical factors that strengthen users' ephemeral content usage and delineate the extent to which these factors affect gratification obtained from such usage. It was found that FOMO, trust, immediacy, and social pressure play significant roles in determining users' gratification. Next, the mediating effect of gratification was found to be crucial for enhancing users' engagement with ephemeral content in social media. The results are consistent with previous research (Ilsever, Cyr, \& Parent, 2007), which found that, when users are impelled by factors like Trust over the platform, Social Pressure, Visual Appeal and ease to use a particular medium, they experience a flow state parallel to gratification in the process. Despite the positive or negative influences of motivations on gratification, they all result in increasing engagement with ephemeral content. An individuals' Interest also affects the behaviour towards the ESNS contents i.e., if the individual is interested in particular content say Fashionable Clothes then the Ephemeral Content published by designer brands and Online Apparel showrooms will be of keen interest to individual and accordingly their behaviour towards those ESNS platforms and content creators will be positive. It is also found that the Visual Appeal on the platform in terms of Perceived Usefulness and Perceived Enjoyment also has an influence over gratification and affects the attitude and behaviour towards the ESNS platform and its usage. The easier the platform to use and more the varied nature of content on the platform catering the needs and usefulness of mass audience can help in having positive correlation towards the ESNS usage and advertisements on them by brands.

The second part of the study i.e., the Netnography Study helps us in understanding the fact that various brands are already using the Ephemeral features of various Social Media Sites and are trying to utilise the features to the fullest in order to monetise on them and win over large audience and stay in trend and be relevant to the customer base. Various brands like Zomato, Bewakoof, Vodafone, Swiggy, Amul, Starbucks, OnePlus, Durex, Internshala and Havells etc. are among those who are very much active on the social media platforms and utilising the ESNS content to the fullest on a daily basis with different intentions. Viewers enjoy while watching relatable Stories shared by any brand and their behaviour also changes for the brand if they find these content interesting. Viewers also share these contents in the form of short-lived coupons, offers, interesting contests, etc. with other ESNS users which results in free promotion for the brand that too at no extra cost. to their family and friends which acts as a further promotion for any product or service. Nowadays, marketing done by any company is done more on social media as it is easy to target most of the audience in online platforms. Also, it is found that many companies try to share memes on social issues in a positive manner so that it will leave a good impact on the mind of the viewers. So, content shared by any company also play a vital role in marketing practices and in changing the behaviour and attitude of the customers. Although study also reveals that various other companies are not utilising these platforms and features of 
ESNS but the trends suggests that in future everyone will be utilising the ways to be creative in using these platforms.

\section{Managerial Implications}

Day by day, usage of social media platforms is increasing. Trends suggest that it would be increasing further in coming time. Facts suggests that with ever growing usage of these social media platforms, use and popularity of features like "stories" will be increasing more than ever. It is also observed that the attention span of humans is decreasing with time hence they focus more on such ephemeral content which is small and temporary. Practically thinking, scope for using this ephemeral content as advertising tool by the content creator would also be increasing. This paper provides the analysis for the brands to understand what the factors are affecting the attitude of usage towards the ESNS as an advertising medium and how readily consumers are accepting advertisements via these platforms in such short-lived formats. Businesses can use these trendy ways of approaching wider audience group which will help them to always being in touch with netizens and these information about recent trends can also be used in designing the ad-campaigns for brands. The paper also showcases the glimpse of current Indian ecosystem about the ESNS platforms and how the brands are utilising the various features available on the sites. The results obtained from such study can provide some excellent knowledge for academics and marketers to learn and implement in their new wave of social network promotional activities and viral marketing. In any attempt to promote a product through social media or to attract audience for limited time deals and sales promotions; marketers must realise this vulnerability of advertisements. Thus, this study is practically very useful and in relevance with current time and hence would prove to be important area of research.

\section{Conclusion}

The rise of social media and social networking websites in the $21^{\text {st }}$ century transformed the communication landscape excitingly. Web 2.0 social media is a powerful medium for finding and targeting customers, engaging them with the brands and leaving an impact on the mind of the customer. From the research, it can be concluded that the professionals in marketing and campaigning have involved Ephemeral content as a way to build bond with the trendy communities, engage the customers, boosts sales, communicate the offers and limited time deals and stay connected with large audience by monetising "moment marketing” at times. In conclusion, this research suggests that users' motivations increase their gratification and enhance their engagement with ephemeral content in social media. It further suggests that need for closure can moderate the impact of gratification on engagement with ephemeral content. The most important element that keeps the audience hooked up to such Ephemeral Content is the Fear of Missing Out along with additional offerings like the Interests of an individual, and Immediacy of action taking in that neck time. Ephemeral Content is rising and is a good source for the brands to encash in and utilise the offerings of the platforms in a unique and creative way.

\section{Acknowledgement}

The paper was presented at the AICTE International Conference on Circular Economy, Management and Industry, Bharati Vidyapeeth's Institute of Management Studies and Research, Navi Mumbai and Apeejay School of Management, Dwarka, Delhi, India. October 2021

\section{References}

Alhabash, S., \& Mengyan, Ma., (2019). A tale of four platforms: motivations and uses of Facebook, Twitter, Instagram, and Snapchat among college students. Journal of Business and Communication 54(1), 44-61, http://dx.doi.org/10.1177/2056305117691544

Amancio, M. (2017). 'Put it in your Story': Digital Storytelling in Instagram and Snapchat Stories. Media \& Communication Studies, 46(4), 111-145. Retrieved from http://urn.kb.se/resolve?urn=urn:nbn:se:uu:diva-324812 
Anderson, K. E. (2015). Getting acquainted with social networks and apps: Snapchat and the rise of ephemeral communication. Journal of Business Management. 32(10), 6-10. http://dx.doi.org/10.1108/LHTN-11-2015-0076.

Ayedee, N., \& Kumar, A. (2020). Indian Education System and growing number of online Conferences: Scenario under COVID-19. Asian Journal of Management, 395-401.

Bayer, J. B., Ellison, N. B., Schoenebeck, S. Y., \& Falk, E. B. (2016). Sharing the small moments: ephemeral social interaction on Snapchat. Information, Communication \& Society, 19(7), 956-977. http://dx.doi.org/10.1080/1369118X.2015.1084349

Belanche, D., Cenjor I., \& Pérez-Rueda, A. (2019). Instagram Stories versus Facebook Wall: an advertising effectiveness analysis. Spanish Journal of Marketing-ESIC. 23(1), 69-94. http://dx.doi.org/10.1108/SJME-09-2018-0042

Billings, A. C., Qiao, F., Conlin, L., \& Nie T. (2015). Permanently Desiring the Temporary? Snapchat, Social Media, and the Shifting Motivations of Sports Fans. Communication \& Sport. 13(2) 1-17. http://dx.doi.org/10.1177/2167479515588760

Cavalcanti, L., Pinto, A., Brubaker, J., \& Dombrowski, L. (2017). Media, Meaning, and Context Loss in Ephemeral Communication Platforms: A Qualitative Investigation of Snapchat”. CSCW 2017: On Mental Models \& Collaboration. 54(7), 125-181. http://dx.doi.org/10.1145/2998181.2998266

Chen, K., \& Cheung, H. L. (2019). Unlocking the power of ephemeral content: The roles of motivations, gratification, need for closure, and engagement. Computers in Human Behavior, 97(2), 67-74. https://doi.org/10.1016/j.chb.2019.03.007

Coa, V. V., \& Setiawan, J. (2017). Analyzing Factors Influencing Behavior Intention to Use Snapchat and Instagram Stories. International Journal of New Media Technology, 4(2), 75-81. https://doi.org/https://doi.org/10.31937/ijnmt.v4i2.783

Flecha-Ortíz, J., Santos-Corrada, M., Dones-González, V., López-González, E., \& Vega, A. (2021). Millennials \& Snapchat: Self-expression through its use and its influence on purchase motivation. Journal of Business Research, 125, 798-805. https://doi.org/10.1016/j.jbusres.2019.03.005

Fox, A. K., Bacile, T. J., Nakhata, C., \& Weible, A. (2018). Selfie-marketing: exploring narcissism and self-concept in visual user-generated content on social media. Journal of Consumer Marketing. https://doi.org/10.1108/JCM-03-2016-1752

Frasier B. (2015). The Rise of Ephemeral Content \& What It Means for Marketers, Journal of Communication \& Society. 4(1), 27-31.

Ganguli, A., Mahajan, S., Srivastava, S., \& Kavitha, R. (2019). Attitude of Social Media Users towards Ephemeral Marketing. International Journal of Research and Analytical Reviews. 6(1), 1750-1761. www.ijrar.org/papers/Attitudeof

Ganzenmuller, R. G. (2014). Snap and Destroy: Preservation Issues for Ephemeral Communications, 62 Buff. L. Rev. 1239 (2014). Journal of Business Research. https://digitalcommons.law.buffalo.edu/buffalolawreview/vol62/iss5/5

Gomez L., Bernabe K., Alvarado, Y., \& Meléndez L. (2018). Snapchat as an Influential Tool for Marketing Communication: An Exploratory Analysis of Brands Usage: An Abstract. In: Krey N., Rossi P. (eds) Back to the Future: Using Marketing Basics to Provide Customer Value. AMSAC 2017. Developments in Marketing Science: Proceedings of the Academy of Marketing Science. Springer, Cham. https://doi.org/10.1007/978-3-319-66023-3_127

Hu, Y., Manikonda, L., \& Kambhampati, S. (2015). What We Instagram: A First Analysis of Instagram Photo Content and User Types. In ICWSM: Proceedings of the Eighth International AAAI Conference on Weblogs and Social Media. 23(3), 595-598. 
https://asupure.elsevier.com/en/publications/What-We-Instagram-A-First-Analysis-ofInstagram-Photo-Content-and-User-Types

Järvinen, J., Ohtonen, R., \& Karjaluoto, H. (2016). Consumer Acceptance and Use of Instagram, In System Sciences (HICSS). 49th Hawaii International Conference, 2227-2236. https://doi.org/10.1109/hicss.2016.279

Karthik, S., Gowda, K. R., \& Banerjee, J. (2021). Click \& Collect Retailing: A Study on Its Influence on the Purchase Intention of Customers. Transnational Marketing Journal, 9(2), 239251.

Meckelborg, K. (2015). Make it disappear: How marketers are winning your attention. Journal of media and technology. 2016; 2(5):123-148. http://www.thenav.ca/2016/11/02/make-itdisappear-how-marketers-are-winning-your-attention/

Morlok, T., Schneider, K., Matt, C. \& Hess, T. (2017). Snap. Share. (Don't) Care? Ephemerality, Privacy Concerns, and the Use of Ephemeral Social Network Sites. Ephemeral Social Network Sites and Privacy Concerns. 11(2), 113-188.

Kumar, A., \& Aggarwal, R. (2018). Sustainable development through social media tools. Journal of Management (JOM), 5(5). 47-51.

Kumar, A., Sowdamini, T., Manocha, S., \& Pujari, P. (2021). Gamification as a Sustainable Tool for HR Managers. Acta Universitatis Bohemiae Meridionalis, 24(2), 1-14.

Lee, C. S., \& Sin, S. C. J. (2016). Why Do People View Photographs on Instagram? In International Conference on Asian Digital Libraries (pp. 339-350). Springer, Cham.

Aharony, N. (2015)."What's App: a social capital perspective", Online Information Review, 39(1), 26 - 42. http://dx.doi.org/10.1108/OIR-08-2014-0177

Phua, J., Jin, S. V., \& Kim, J. J. (2017). Uses and gratifications of social networking sites for bridging and bonding social capital: A comparison of Facebook, Twitter, Instagram, and Snapchat. Computers in Human Behavior, 72, 115122. https://doi.org/10.1016/j.chb.2017.02.041

Phua, J., Jin, S. V., \& Kim, J. J. (2017). Uses and gratifications of social networking sites for bridging and bonding social capital: A comparison of Facebook, Twitter, Instagram, and

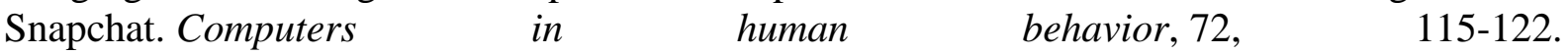
https://doi.org/10.1016/j.chb.2017.02.041

Robertson, T. S., Gatignon, H., \& Cesareo, L. (2018). Pop-ups, ephemerality, and consumer experience: the centrality of buzz. Journal of the Association for Consumer Research, 3(3), 425-439. http://dx.doi.org/10.1086/698434

Shaikh, A. A., Kumar, M., Syed, D., Ali, A., \& Shaikh, M. Z. (2021). A Two-Decade Literature Review on Challenges Faced by SMEs in Technology Adoption. Academy of Marketing Studies Journal, 25(3).

Viknesh, R., Gowda, K. R., \& Banerjee, J. (2021). A Study on Decision Paralysis in Customers with Special Reference to Placing Order in Restaurant. Transnational Marketing Journal, 9(2), 253-266.

Wakefield, L. T. (2016). Why Do I Want to Be Your Friend? Engaging with Brands in Ephemeral Media (Doctoral dissertation).

Wakefield, L. T., \& Wakefield, R. L. (2018). Anxiety and ephemeral social media use in negative eWOM creation. Journal of Interactive Marketing, 41, 44-59. https://doi.org/10.1016/j.intmar.2017.09.005 